\title{
Solar PV MPPT Control Technology Application Analysis
}

\author{
Shuling Feng, Shaoyi Li, Renbo Xu and Zhilin Ding
}

(NanChang Institute of Science and Technology, Nanchang,330108)

Keywords: Renewable Energy; Photovoltaic Generation; MPPT

\begin{abstract}
Photovoltaic (PV) power generation generates DC power during operation. When connected to a load or the power grid, it needs to convert electrical energy to facilitate its use. From the development of photovoltaic power generation, the paper analyzes the system composition of photovoltaic power generation, describes the categories of photovoltaic modules in the structural composition, and finally introduces the model of photovoltaic cells and the BOOST topology and current output of photovoltaic modules in the MPPT control mode. Control expressions.
\end{abstract}

\section{Introduction}

The economic growth and the development and utilization of energy have dried up traditional energy sources, which has brought tremendous pressure on the development of countries around the world, especially the economic development of developing countries. At the same time, the consumption of traditional energy sources has brought about a greenhouse effect and environmental issues. As countries continue to explore new energy fields, sustainable energy sources such as photovoltaics, wind power, and hydropower are paid attention to. Solar energy is favored because of its unlimited access and low pollution.

According to statistics, the world's energy will usher in a tremendous transformation, and solar energy, as a new energy source, will occupy a larger proportion in power generation systems. It is estimated that in the 2030s, renewable energy accounts for more than $30 \%$ of the total energy, of which the photovoltaic industry accounts for more than $8 \%$. By the end of the century, new energy will become the main energy source ${ }^{[1]}$.

\section{Photovoltaic Development Status}

According to a survey conduccted by the European Photovoltaic Industry Association (EPIA), the photovoltaic industry has developed rapidly and the photovoltaic market has been greatly affected by policies. Table 1 shows the statistics of photovoltaic installation capacity statistics in various countries of the world ${ }^{[1]}$. From the statistics of the chart, it can be found that the installed capacity of photovoltaic power in all countries shows a rapid growth.

Table 1 National PV Installation Capacity Table (MW)

\begin{tabular}{cccccccc}
\hline & China & America & $\begin{array}{c}\text { Asia } \\
\text { Pacific }\end{array}$ & Europe & Middle East & Others & Total \\
\hline 2000 & 19 & 2 & 126 & 58 & - & 88 & 293 \\
2001 & 5 & 3 & 128 & 133 & - & 56 & 323 \\
2002 & 19 & 30 & 190 & 134 & - & 80 & 454 \\
2003 & 10 & 48 & 230 & 202 & - & 77 & 566 \\
2004 & 10 & 61 & 282 & 705 & 1 & 29 & 1088 \\
2005 & 8 & 82 & 304 & 985 & 0 & 10 & 1389 \\
2006 & 10 & 110 & 325 & 997 & 0 & 105 & 1547 \\
2007 & 20 & 166 & 271 & 2023 & 1 & 42 & 2524 \\
2008 & 40 & 366 & 530 & 5100 & 1 & 76 & 6661 \\
2009 & 160 & 500 & 745 & 5833 & 22 & 80 & 7340 \\
2010 & 500 & 1082 & 1578 & 13616 & 46 & 284 & 17107 \\
2011 & 2500 & 2181 & 2562 & 22407 & 125 & 508 & 30282 \\
2012 & 3500 & 3774 & 4646 & 17580 & 365 & - & 29865 \\
2013 & 11300 & 5153 & 9833 & 10253 & 383 & 85 & 37007 \\
\hline
\end{tabular}


Compared to developed countries, domestic photovoltaic development is relatively backward. China's photovoltaic industry started in the 1970s, and the cost of development continued to decline after more than 40 years in the 1990s. Statistics show that China's PV cell output for the second consecutive year in 2007-2008 was the first in the world and it showed a trend of rapid development every year. Domestic newly installed capacity and inverters increased year by year.

\section{Micro-photovoltaic Grid-connected System Structure and Operation Analysis}

\section{Voltage Boosting and Inverter Type of Photovoltaic Grid-connected System ${ }^{[2]}$}

Due to factors such as the manufacturing process and the photovoltaic panel power generation, the output current voltage of a single photovoltaic panel is limited. Therefore, in the actual power generation process, the corresponding series or parallel connection method is generally set to increase the voltage and power level according to the demand. The DC-DC step-up converter and the DC-AC inverter can be used. The former provides a channel for the boosting process of the voltage, and the latter provides a bridge for the grid connection of the microgrid. Figure 1 shows the structure diagram of the electrical structure of a common microgrid, and Figure 1 (a) shows a stcuture diagram of a photovoltaic grid-connected system. The photovoltaic system includes a photovoltaic array, an MPPT control module, an energy storage system module (ES), and an external DC load module (DC), inverter module (INVERTER), external AC load module (AC), transformer module (Transformer), and modules connected to the grid, etc. Figure 1 (b) shows the commonly used structure diagram of micro-photovoltaic power ge, which are mostly implemented using centralized, serial and multi-string solutions.

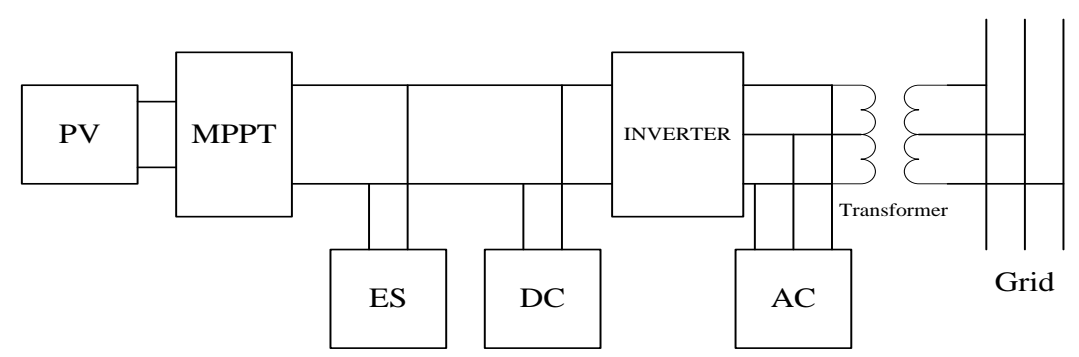

(a) Structure Diagram of a Photovoltaic Grid-connected System

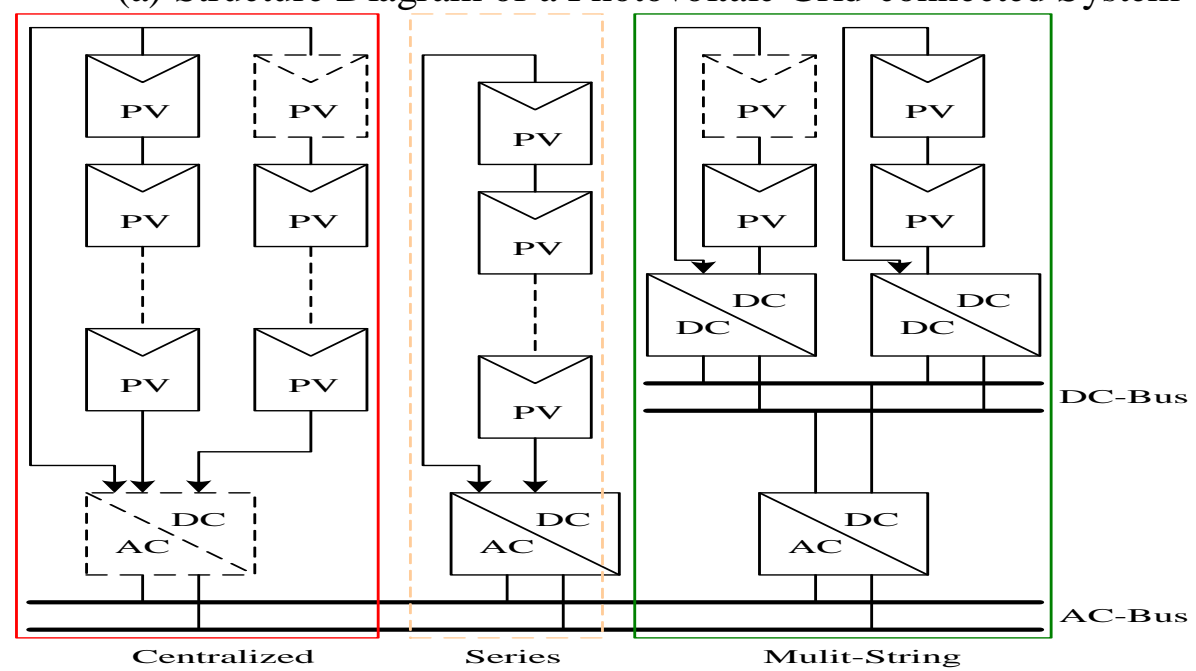

(b) Commonly Used Structure Diagram of Micro-photovoltaic Power Generation

Figure 1. Structure Diagram of the Electrical Structure of a Common Microgrid 


\section{PV Power Station Installation Types}

When PV arrays are arranged in a fixed arrangement, the best dip angle design should take into account the local monthly average irradiance for multiple years, direct component irradiance, scattered component irradiance, wind speed, rainwater, snow and other weather conditions [ 3], and meet the following requirements:

1) For grid-connected photovoltaic power generation systems, the tilt angle of the PV array should maximize the annual radiation dose on the inclined surface;

2) For stand-alone photovoltaic grid-connected power generation systems, the tilt angle of the PV array should be such that the minimum irradiance on the monthly inclined surface is subject to higher exposure;

3) For photovoltaic power plants with special requirements, the design dip and array spacing of PV arrays can be determined based on the specific conditions and economic and technical comparison.

\section{Photovoltaic Panel Structure and Operation Mode Analysis}

Through the collection of domestic and foreign documents, the commonly used control methods and topological structures of the PV array components in the microgrid PV system are compared during operation, and their characteristics are compared. The perturbation observation method and BOOST step-up conversion circuit are selected to achieve corresponding functions, and the DSP control board platform is adopted to get samples of the software part of the disturbance observation and feedback signal function. Figure 2 shows the maximum power point tracking system for the photovoltaic cell model and the BOOST circuit.

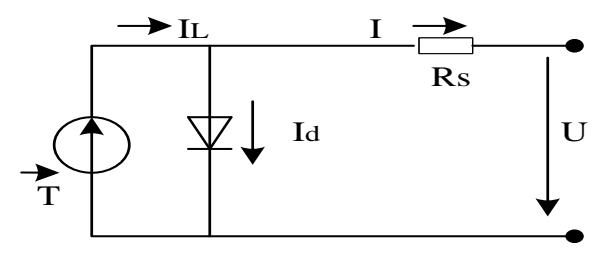

(a) Photovoltaic Cell Equivalent Circuit Model

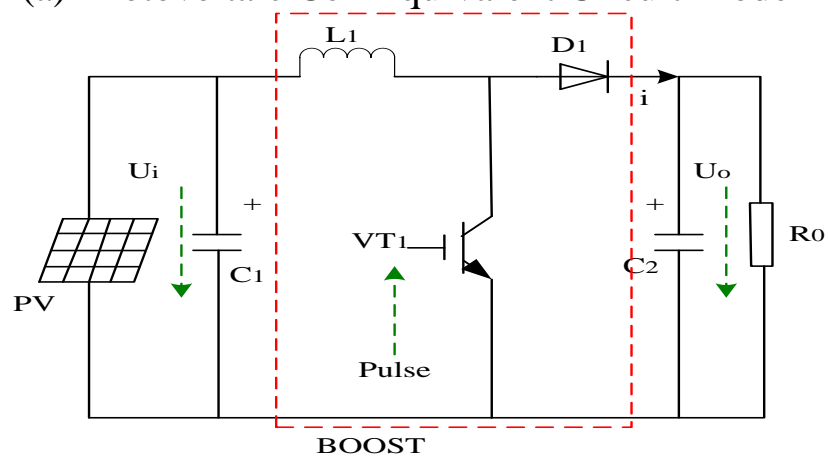

(b) Photovoltaic Cell Pack MPPT Control System Schematic

Figure 2 Photovoltaic Cell Model and Photovoltaic Cell Pack MPPT Control System Schematic

Photovoltaic cell output characteristic equation shows as follows ${ }^{[3]}$ :

$$
I=I_{L}-I_{d}=I_{L}-I_{o}\left\{\exp \left[\frac{q}{A k T}\left(U+I R_{s}\right)\right]-1\right\}
$$

In the formula:

$\mathrm{I}_{\mathrm{L}}$-photocurrent, unit A;

$\mathrm{I}_{\mathrm{O}}$-reverse saturation current, unit $\mathrm{A}$;

q-electron charge, unit $1.6 \times 10-19 C$;

k-Boltzmann constant, unit $1.38 \times 10-23 \mathrm{~J} / \mathrm{K}$;

T-absolute temperature, unit $\mathrm{K}$;

A-PN knot ideal factor;

$\mathrm{R}_{\mathrm{S}}$-series resistance, unit $\Omega$ 
$\mathrm{R}_{\mathrm{sh}}$-parallel resistance, unit $\Omega$

\section{Conclusion}

Photovoltaic power generation is an important part of new energy forms. This article starts with the status of international and domestic photovoltaic power generation and summarizes the international and domestic development trends of photovoltaic power generation. The trend shows that photovoltaic power generation in new energy power generation is developing rapidly, showing gradual growth. Then, the specific structure of photovoltaic power generation and its connection method are described; the structure diagram of the photovoltaic power generation structure is given and three forms of photovoltaic power generation modules are introduced. What's more, the circuit model of the battery in photovoltaic power generation and the topological structure of MPPT control system is analyzed, which reveals that by using the control system of MPPT can make the photovoltaic battery pack have better power generation characteristics during the operation process.

\section{Acknowledgement}

Project funding: Nanchang DME Photoelectric Engineering Key Laboratory (No.NCZDSY -004)

\section{References}

[1] Chen Xiaojing, Research on Photovoltaic System MPPT Technology Under Partially Shaded Conditions Based on Particle Swarm Optimization[D], Master thesis of Hefei University of Technology, 2014

[2] Wang Lu, Research on Micro-photovoltaic Grid-connected Inverters[D], Nanjing University of Aeronautics and Astronautics, 2012

[3] Li Yingzi, Design and Application of Solar Photovoltaic Power Generation System[M], Mechanical Industry Press, January 2016

[4] Azadeh Safari, Saad Mekhilef, Simulation and Hardware Implementation of Incremental Conductance MPPT With Direct Control Method Using Cuk Converter[J], IEEE TRANSACTIONS ON INDUSTRIAL ELECTRONICS, VOL. 58,NO.4,APRIL,2011: 1154-1161

[5] Sun Yuanyuan, Research on Photovoltaic Grid-connected Inverter MPPT Technology[D], Master Degree Thesis of Nanjing University of Aeronautics and Astronautics, 2010

[6] Ahmed K.Abdelsalam, Ahmed M.Massoud, Shehab Ahmed,Prasad N.Enjeti,High-Performance Adaptive Perturb and Observe MPPT Technique for Photovoltaic-Based Microgrids[J], IEEE TRANSACTIONS ON POWER ELECTRONICS,VOL,26,no.4,APRIL,2011:1010-1021

[7] Zhang Chao, Research on MPPT and Islanding Detection Technology for Photovoltaic Grid-connected Power Generation System [D], Doctoral dissertation of Zhejiang University, 2006

[8] Zhong Jie, Research on Photovoltaic Grid-connected Inverter MPPT and Double Closed-loop Control Technology[D], Master thesis of Southwest Jiaotong University, 2013

[9] Hegazy Rezk,El-Sayed Hasaneen, A new MATLAB/Sinulink model of triple-junction solar cell and MPPT based on artificial neural networks for photovoltaic energy systems[J], Ain Shams Engineering Journal(2015)6,873-881.

[10] Qiang Mei, Mingwei Shan, Liying Liu, and Josep M.Guerrero, A Novel Improved Variable Step-Size Incremental-Resistance MPPT Method for PV Systems[J]. IEEE TRANSACTIONS ON INDUSTRIAL ELECTRONICS, 2011,58(6): 2425-2434. 